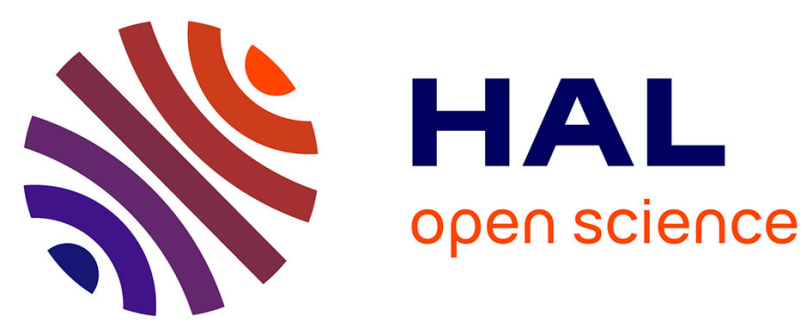

\title{
Water Vapor Does Not Catalyze the Reaction between Methanol and $\mathrm{OH}$ Radicals
}

Wen Chao, Jim Jr-Min lin, Kaito Takahashi, Alexandre Tomas, Lu Yu, Yoshizumi Kajii, Sébastien Batut, Coralie Schoemaecker, Christa Fittschen

\section{- To cite this version:}

Wen Chao, Jim Jr-Min lin, Kaito Takahashi, Alexandre Tomas, Lu Yu, et al.. Water Vapor Does Not Catalyze the Reaction between Methanol and $\mathrm{OH}$ Radicals. Angewandte Chemie International Edition, 2019, 58 (15), pp.5013-5017. 10.1002/anie.201900711 . hal-02321920

\author{
HAL Id: hal-02321920 \\ https://hal.science/hal-02321920
}

Submitted on 13 Nov 2020

HAL is a multi-disciplinary open access archive for the deposit and dissemination of scientific research documents, whether they are published or not. The documents may come from teaching and research institutions in France or abroad, or from public or private research centers.
L'archive ouverte pluridisciplinaire HAL, est destinée au dépôt et à la diffusion de documents scientifiques de niveau recherche, publiés ou non, émanant des établissements d'enseignement et de recherche français ou étrangers, des laboratoires publics ou privés. 


\title{
1 Water Vapor does not Catalyze the Reaction between Methanol and $\mathrm{OH}$ Radicals
}

\author{
Wen Chao, ${ }^{[b]} \mathrm{Jim}$ Jr-Min Lin, ${ }^{[b]}$ Kaito Takahashi, ${ }^{[b]}$ Alexandre Tomas, ${ }^{[c]}$ Lu Yu, ${ }^{[d]}$ Yoshizumi Kajii, ${ }^{[d]}$ \\ Sébastien Batut, ${ }^{[a]}$ Coralie Schoemaecker ${ }^{[a]}$, and Christa Fittschen* ${ }^{\text {[a] }}$
}

\begin{abstract}
Recent works [Jara-Toro et al., Angew. Chem. Int. Ed. 2017, 56, 2166 and PCCP 2018, 20, 27885] suggest that the rate coefficient of $\mathrm{OH}$ reactions with alcohols would increase by up to 2 times from dry to high humidity. This finding would have an impact on the budget of alcohols in the atmosphere and that it may explain differences in measured and modeled methanol concentrations. The results were based on a relative technique carried out in a small Teflon bag, which might suffer from wall reactions. We have reinvestigated this effect using a direct fluorescence probe of $\mathrm{OH}$ radicals, and no catalytic effect of $\mathrm{H}_{2} \mathrm{O}$ could be found. Experiments in a Teflon bag were also carried out, but we were not able to reproduce the results of Jara-Toro et al. Further theoretical calculations show that the water-mediated reactions have negligible rates compared to the bare reaction and that even though water molecules can lower the barriers of reactions, it cannot make up for the entropy cost.
\end{abstract}

Methanol $\left(\mathrm{CH}_{3} \mathrm{OH}\right)$ is one of the most abundant oxygenated volatile organic compounds (OVOC) in the atmosphere ${ }^{[1,}{ }^{[2]}$. Direct emissions are the main source, but some oxidation pathways of methane also contribute to its abundance,

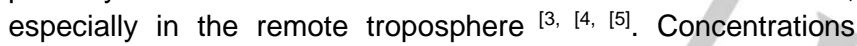
range from 1-15 ppbv in the continental boundary layer and up to $1 \mathrm{ppbv}$ in the remote troposphere ${ }^{[6,[7]}$. Despite numerous efforts, global atmospheric chemical models are presently unable to reconcile the modeled and measured methanol concentrations $[7,[8,[9]$

The atmospheric degradation of $\mathrm{CH}_{3} \mathrm{OH}$ is governed by its reaction with $\mathrm{OH}$ radicals, which proceeds by abstraction of $\mathrm{H}$ atoms from either the methyl or the hydroxyl site ${ }^{[10]}$. The rate coefficient shows a non-Arrhenius behavior and increases at

[a] Sébastien Batut, Dr. Coralie Schoemaecker, Dr. Christa Fittschen Physical Chemistry of Combustion and Atmospheric Processes University Lille / CNRS UMR 8522

Cité Scientifique, Bât. C11, 59655 Villeneuve d'Ascq, France E-mail: Christa Fittschen@univ-lille.fr

[b] Wen Chao, Dr. Jim Jr-Min Lin, Dr. Kaito Takahashi Institute of Atomic and Molecular Sciences Academia Sinica

Taipei 10617, Taiwan

[c] Prof. Dr. Alexandre Tomas

Sciences de l'Atmosphère et Génie de l'Environnement SAGE IMT Lille Douai

941 Rue Charles Bourseul, 59508 Douai, France

[d] Lu Yu, Prof. Dr. Yoshizumi Kajii

Atmospheric Chemistry, Department of Natural Sources

University of Kyoto

Yoshida-Honmachi, Sakyo-ku, Kyoto 606-8501, Japan

Supporting information for this article is given via a link at the end of the document. temperatures below $200 \mathrm{~K}$, due to enhanced stabilization of a pre-reactive $\mathrm{H}$-bonded complex that can undergo tunneling ${ }^{[10]}$. The rate coefficient at room temperature $(298 \mathrm{~K})$ has been

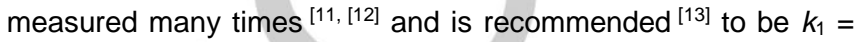
$9.0 \times 10^{-13} \mathrm{~cm}^{3} \mathrm{~s}^{-1}$.

Very recently, Jara-Toro et al. ${ }^{[14]}$ reported that the reaction of $\mathrm{OH}$ with $\mathrm{CH}_{3} \mathrm{OH}$ is significantly catalyzed by water (enhanced by a factor of 2 between 20 to $95 \%$ of relative humidity) even at 294 $\mathrm{K}$. The same group also reported the water catalysis effect on reactions of $\mathrm{OH}$ with ethanol and $\mathrm{n}$-propanol ${ }^{[15]}$. Their results are based on a well-known relative method, where the consumption of the alcohol is measured relative to the consumption of a reference compound $\left(\mathrm{C}_{5} \mathrm{H}_{12}\right)$ following their simultaneous reactions with $\mathrm{OH}$ radicals. The reactions took place in a 80 liter Teflon bag, and $\mathrm{OH}$ radicals were generated continuously from the $254 \mathrm{~nm}$ photolysis of $\mathrm{H}_{2} \mathrm{O}_{2}$. The ratio of the consumption of $\mathrm{CH}_{3} \mathrm{OH}$ versus the consumption of $\mathrm{C}_{5} \mathrm{H}_{12}$ gives the ratio of the rate coefficients, $k_{\mathrm{CH}_{3} \mathrm{OH}+\mathrm{OH}} / k_{\text {Ref+OH}}$. This type of experiments was carried out at different relative humidity $(\mathrm{RH})$ up to $95 \%$, and it was found that the ratio increased with increasing $\mathrm{RH}$. Under the assumption that the rate of the $\mathrm{OH}$ reaction with unpolar $\mathrm{C}_{5} \mathrm{H}_{12}$ is independent on $\mathrm{RH}$, this increased ratio was assigned to an increased rate of $\mathrm{OH}$ reaction with $\mathrm{CH}_{3} \mathrm{OH}$ due to water catalysis. More surprisingly, they found a quadratic dependence of the rate enhancement with $\mathrm{RH}$, and speculated that this effect was dismissed in earlier works, because earlier experiments were commonly carried out under low $\mathrm{RH}$, where the water effect would be too weak to observe. Accompanying theoretical work proposed a mechanism of reaction barrier lowering by adding $\mathrm{H}_{2} \mathrm{O}$. However, no rate coefficient has been calculated to estimate the impact of this lowering in the reaction barrier heights.

Using the rate coefficients taking into account the water catalytic effect could decrease the atmospheric lifetime of $\mathrm{CH}_{3} \mathrm{OH}$ by a factor of 2 in tropical region with high $\mathrm{RH}$, which would have a non-negligible effect on the global $\mathrm{CH}_{3} \mathrm{OH}$ budget. It is therefore important to verify this new finding by using different methods. Indeed, the experiments of Jara-Toro et al. have been carried out in a relatively small Teflon bag, where heterogeneous consumption of $\mathrm{CH}_{3} \mathrm{OH}$ on the walls may take place. This effect may increase with $\mathrm{RH}$ and may become complicated when photochemistry occurs (which produces radicals and radical reactions may change the wall property). They did not vary the surface to volume ratio to quantify this effect.

In this work, we have reinvestigated the influence of $\mathrm{H}_{2} \mathrm{O}$ on the rate coefficient of $\mathrm{OH}$ reaction with $\mathrm{CH}_{3} \mathrm{OH}$ using a direct method: laser photolysis coupled to a time-resolved detection of $\mathrm{OH}$ radicals by laser induced fluorescence (LIF) after gas expansion (FAGE - Fluorescence Assay by Gas Expansion) [12, [16]. We have also repeated experiments using the same relative method as Jara-Toro et al., and in addition to varying $\mathrm{RH}$, we 
have also largely varied the gas volume in the Teflon bag in order to vary the surface to volume ratio. Finally, theoretical calculations have been carried out for a refined analysis of possible $\mathrm{H}_{2} \mathrm{O}$ catalysis pathways.

The FAGE technique, initially developed for the quantification of $\mathrm{OH}$ radicals in the atmosphere, allows following $\mathrm{OH}$ concentrations in a selective and sensitive way even under atmospheric conditions, i.e. high $\mathrm{O}_{2}$ and $\mathrm{H}_{2} \mathrm{O}$ concentrations, which proves difficult with in-situ LIF due to strong quenching of $\mathrm{OH}$ fluorescence by $\mathrm{O}_{2}$ and $\mathrm{H}_{2} \mathrm{O}$. Here, FAGE has been coupled to a laser photolysis reactor (Figure 1) ${ }^{[16,[17]}$ for a pulsed initiation of the reaction between $\mathrm{OH}$ and $\mathrm{CH}_{3} \mathrm{OH}$. Briefly, $\mathrm{OH}$ radicals were generated by pulsed photolysis of a mixture of ozone and water $\left(\mathrm{O}_{3}+h v \rightarrow \mathrm{O}\left({ }^{1} \mathrm{D}\right)+\mathrm{O}_{2} ; \mathrm{O}\left({ }^{1} \mathrm{D}\right)+\mathrm{H}_{2} \mathrm{O} \rightarrow 2 \mathrm{OH}\right)$. The $266 \mathrm{~nm}$ photolysis laser beam (4th harmonic of $\mathrm{Nd}: \mathrm{YAG}$ Laser, Quantel Brilliant, 20 $\mathrm{mJ}$ ) was expanded to a diameter of $\sim 5 \mathrm{~cm}$ before entering the photolysis cell. The photolysed gas mixture was continuously expanded from near atmospheric pressure within the photolysis cell to around 1 Torr into the FAGE cell through a pinhole ( $1 \mathrm{~mm}$ diameter). $\mathrm{OH}$ radicals were resonantly excited at high repetition rate by the probe laser (308 $\mathrm{nm}$, Sirah Dye laser, $5000 \mathrm{~Hz}, \sim 3.5 \mathrm{~mW}$ ). The LIF signal of $\mathrm{OH}$ was detected in a time resolved manner by a channel photomultiplier tube (Perkin Elmer) and recorded by a National Instrument DAQ card and computer. This way, temporal $\mathrm{OH}$ profiles were recorded from each photolysis shot with time stamps every $200 \mu \mathrm{s}$ and, depending on the signal intensity, individual profiles were added from 30 up to 480 photolysis laser shots. We further binned 5 data points together (final time bin is $1 \mathrm{~ms}$ ) to enhance the signal-to-noise ratio.

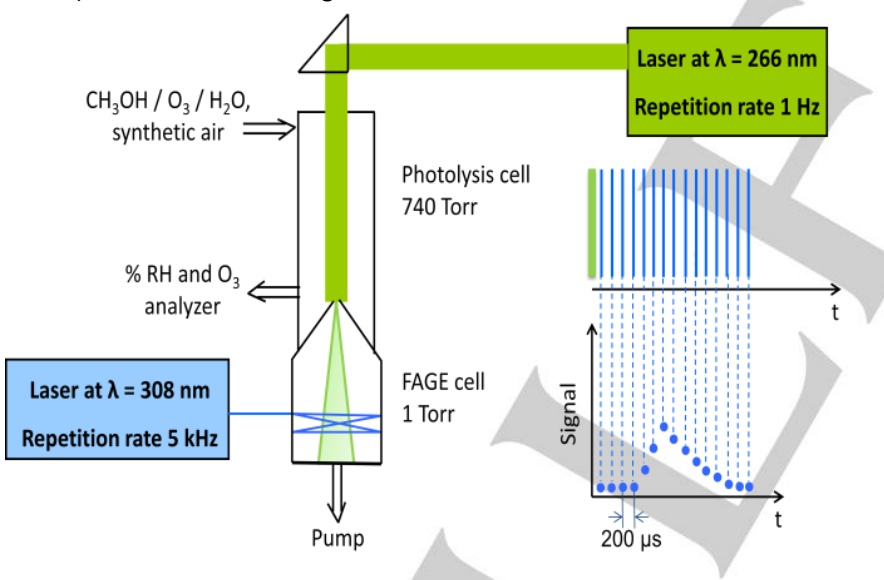

Figure 1. Schematic view of the FAGE set-up

Water vapour was added to the reaction mixture by bubbling a fraction of the main flow (composed of synthetic air) through a glass bottle containing high purity water (TOC $<10 \mathrm{ppb}$ ). The $\mathrm{H}_{2} \mathrm{O}$ concentration was varied by changing the fraction of the main flow passing through the water bottle. A minimum $\mathrm{H}_{2} \mathrm{O}$ concentration of $1 \times 10^{17} \mathrm{~cm}^{-3}(\mathrm{RH} \approx 17 \%)$ was necessary to generate enough $\mathrm{OH}$ radicals, the highest $\mathrm{H}_{2} \mathrm{O}$ concentration $\left(6.1 \times 10^{17} \mathrm{~cm}^{-3}, \mathrm{RH} \approx 92 \%\right)$ was reached by passing the entire air flow through the water bottle. The $\mathrm{H}_{2} \mathrm{O}$ concentrations were measured at the exit of the photolysis cell using a commercial dew point hygrometer (Mitchel S8000 Integrale).
Test experiments were carried out using $\mathrm{CO}$ as a reaction partner for $\mathrm{OH}$. Different concentrations of $\mathrm{CO}$ were added to the main flow through calibrated flow meters and a rate constant of $(2.3 \pm 0.3) \times 10^{-13} \mathrm{~cm}^{3} \mathrm{~s}^{-1}$ was obtained, in good agreement with literature data ${ }^{[13]}$ and no dependence on the water concentration was observed. See SI for more details.

The rate coefficient for the reaction of $\mathrm{CH}_{3} \mathrm{OH}$ with $\mathrm{OH}$ was then measured at $\mathrm{RH}$ up to $92 \%$. Figure 2 shows typical $\mathrm{OH}$ decay profiles in the presence of different $\mathrm{CH}_{3} \mathrm{OH}$ concentrations. The $\mathrm{OH}$ loss in the absence of $\mathrm{CH}_{3} \mathrm{OH}$ (black symbols in Figure 2) is due to reaction of $\mathrm{OH}$ with impurities (trace amounts in the synthetic air or in the water) as well as through diffusion/dilution of $\mathrm{OH}$ into the non-photolysed volume.

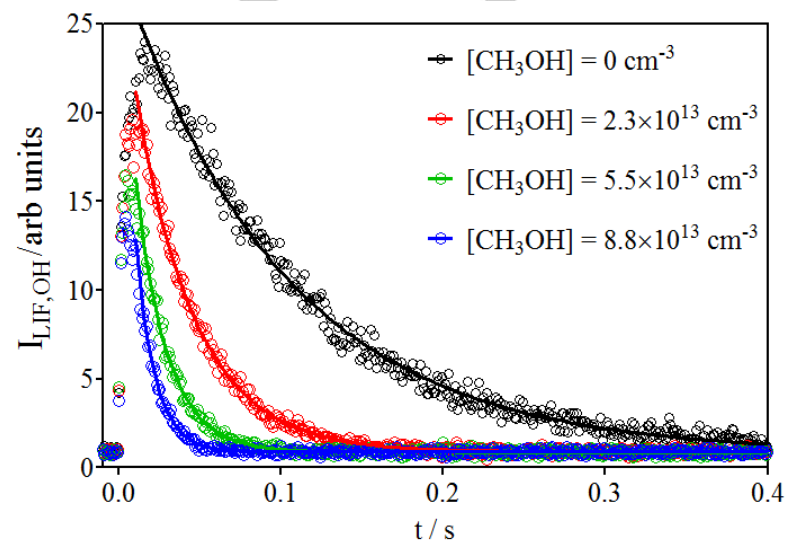

Figure 2. Typical $\mathrm{OH}$ decay profiles in the presence of different $\mathrm{CH}_{3} \mathrm{OH}$ concentrations. $\left[\mathrm{H}_{2} \mathrm{O}\right]=5.7 \times 10^{17} \mathrm{~cm}^{-3}$. Solid lines represent a fit to an exponential decay between 0.015 and $0.4 \mathrm{~s}$.

The $\mathrm{OH}$ decays can be described as the sum of these losses:

$$
-\frac{\mathrm{d}[\mathrm{OH}]}{\mathrm{dt}}=\left(k_{\text {loss }}+k_{1}\left[\mathrm{CH}_{3} \mathrm{OH}\right]\right)[\mathrm{OH}]
$$

with $k_{1}$ being the rate coefficient for the reaction between $\mathrm{OH}$ radcials and $\mathrm{CH}_{3} \mathrm{OH}$. With $\left[\mathrm{CH}_{3} \mathrm{OH}\right]$ being in large excess over $[\mathrm{OH}],\left[\mathrm{CH}_{3} \mathrm{OH}\right]$ can be considered as constant and the $\mathrm{OH}$ decay can be described by an exponential decay, with the observed decay rate being

$$
k_{\text {obs }}=k_{\text {loss }}+k_{1}\left[\mathrm{CH}_{3} \mathrm{OH}\right] \text {. }
$$

Plotting the decay rates of Figure 2-type signals as a function of $\left[\mathrm{CH}_{3} \mathrm{OH}\right]$ leads to a straight line, with the slope being the rate coefficient $k_{1}$, and the intercept $k_{\text {loss }}$ representing the sum of all other losses. Figure 3 shows the decay rates of 6 series of experiments (see $\mathrm{SI}$ for detailed results) at different $\mathrm{H}_{2} \mathrm{O}$ concentrations ( $\mathrm{RH}$ between 18 and $92 \%$ ), where the $\mathrm{CH}_{3} \mathrm{OH}$ concentration has been varied for each $\mathrm{RH}$ between $2-9 \times 10^{13}$ $\mathrm{cm}^{-3}$.

It can be seen that the intercepts slightly differ for different series. This can be explained by the synthetic air gas cylinders of different quality used during the period of experiments, which lasted for weeks. However, the slopes are the same for all $\mathrm{RH}$, which means that the rate coefficient obtained for conditions with different $\mathrm{H}_{2} \mathrm{O}$ concentrations are the same, no dependence of $k_{1}$ on $\left[\mathrm{H}_{2} \mathrm{O}\right]$. This is illustrated in Figure 4, where the slopes of the linear regressions from Figure 3 are plotted as a function of the $\mathrm{RH}$. 


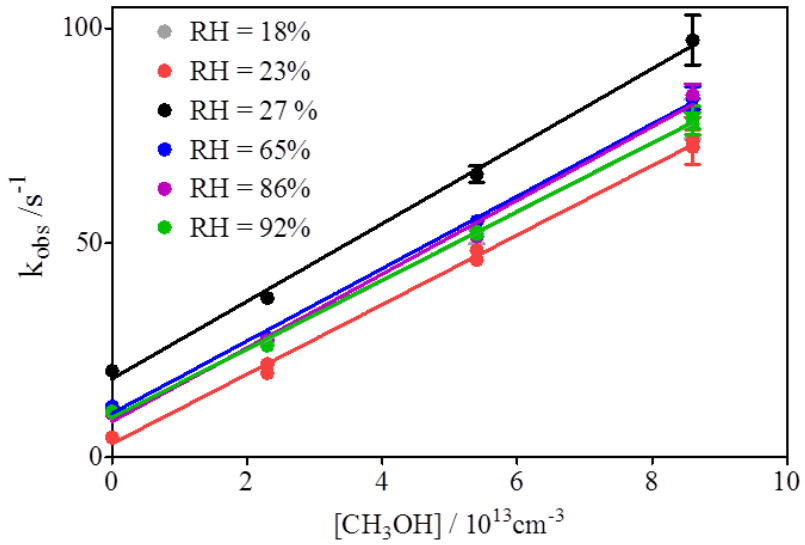

Figure 3. Plot of $\mathrm{OH}$ decay rates $k_{\text {obs }}$ as a function of $\mathrm{CH}_{3} \mathrm{OH}$ concentration for different $\mathrm{RH}$. Error bars show statistical uncertainty only, full lines correspond to linear regression.

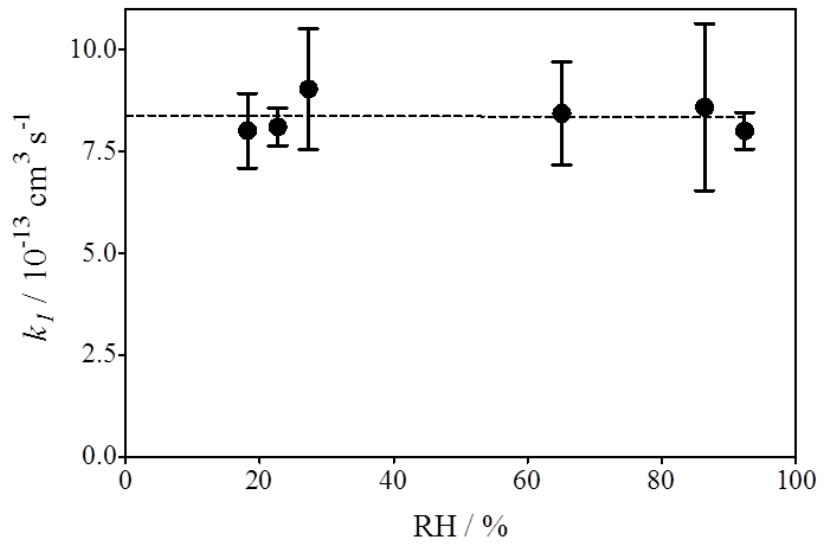

Figure 4. Plot of the rate coefficient $k_{1}$ such as obtained from the linear regression in Figure 3 as a function of $\mathrm{RH}$. Error bars show statistical error only $(95 \%$ confidence interval). Dashed line represents linear regression through all data points.

Additional series of experiments have been carried out by keeping the $\mathrm{CH}_{3} \mathrm{OH}$ concentration stable and varying the $\mathrm{H}_{2} \mathrm{O}$ concentration. Figure 5 shows the normalized $\mathrm{OH}$ decays for 3 different $\mathrm{RH}$ between 36 and $83 \%$, no systematic increase in the $\mathrm{OH}$ decay rate can be observed.

Teflon bag experiments have been carried out in order to try to reproduce and understand the water effect in the bag experiments such as observed by Jara-Toro et al. Experiments have been carried out in a 400 liter Teflon bag ${ }^{[18]}$ using the relative rate method with $n$-pentane as reference compound: $\mathrm{CH}_{3} \mathrm{OH}$ has been quantified by FTIR spectroscopy, while npentane was quantified by $\mathrm{GC} / \mathrm{FID}, \mathrm{OH}$ radicals have been generated by the photolysis of $\mathrm{CH}_{3} \mathrm{ONO}$, a common precursor for $\mathrm{OH}$ radicals in chamber experiments. Compared to $\mathrm{H}_{2} \mathrm{O}_{2}$ (which has been used by Jara-Toro et al.), $\mathrm{NO}$ (and $\mathrm{NO}_{2}$ from the oxidation of NO) is a by-product of this precursor. However, it is not expected to influence the result of this study, as neither $\mathrm{NO}$ nor $\mathrm{NO}_{2}$ will react with $\mathrm{CH}_{3} \mathrm{OH}$ or with $\mathrm{C}_{5} \mathrm{H}_{12}$. The bag was filled with either 400 liters or with 100 liters in order to vary the surface to volume ratio, and experiments with 3 different $\mathrm{RH}$ have been carried out: dry air $(\mathrm{RH}<5 \%), 40$ and $90 \%$.

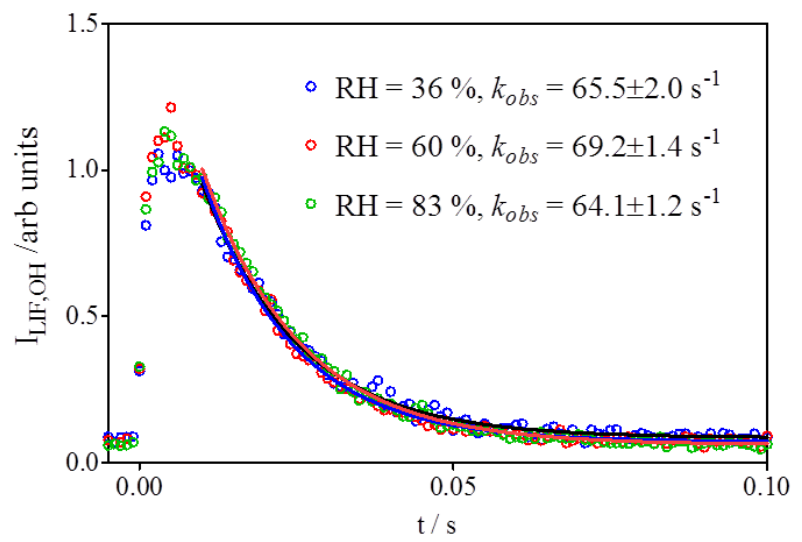

Figure 5. Normalized $\mathrm{OH}$ LIF intensities as a function of time for 3 experimental conditions with identical $\mathrm{CH}_{3} \mathrm{OH}$ concentrations $\left(5.4 \times 10^{13} \mathrm{~cm}^{-3}\right)$ but different $\mathrm{RH}$. Decay rate was obtained by fitting traces to an exponential decay between 0.01 and $0.2 \mathrm{~s}$.

Figure 6 summarizes the results: the upper graph shows the plot of the consumption of $\mathrm{CH}_{3} \mathrm{OH}$ versus the consumption of $\mathrm{C}_{5} \mathrm{H}_{10}$ for the 6 different experiments, the lower graph shows the slopes of the linear regressions. The average of all experiments yields a slope of 0.26 , leading with the rate coefficient of $k$ $\mathrm{C}_{5} \mathrm{H}_{12}+\mathrm{OH}=3.8 \times 10^{-12} \mathrm{~cm}^{3} \mathrm{~s}^{-1}$ to a rate coefficient $k_{1}=9.9 \times 10^{-13}$ $\mathrm{cm}^{3} \mathrm{~s}^{-1}$, in agreement with literature. This slope would increase with increasing $\mathrm{RH}$ if $k_{1}$ increases with $\mathrm{RH}$, however in our experiments we observed, if anything, a small decrease with increasing $\mathrm{RH}$. We also do not see any effect when changing the surface to volume ratio by a factor of 4 , indicating that our results are not affected by heterogeneous processes in our Teflon bag. No explanation can be given why Jara-Toro et al. observed an increase in the ratio.
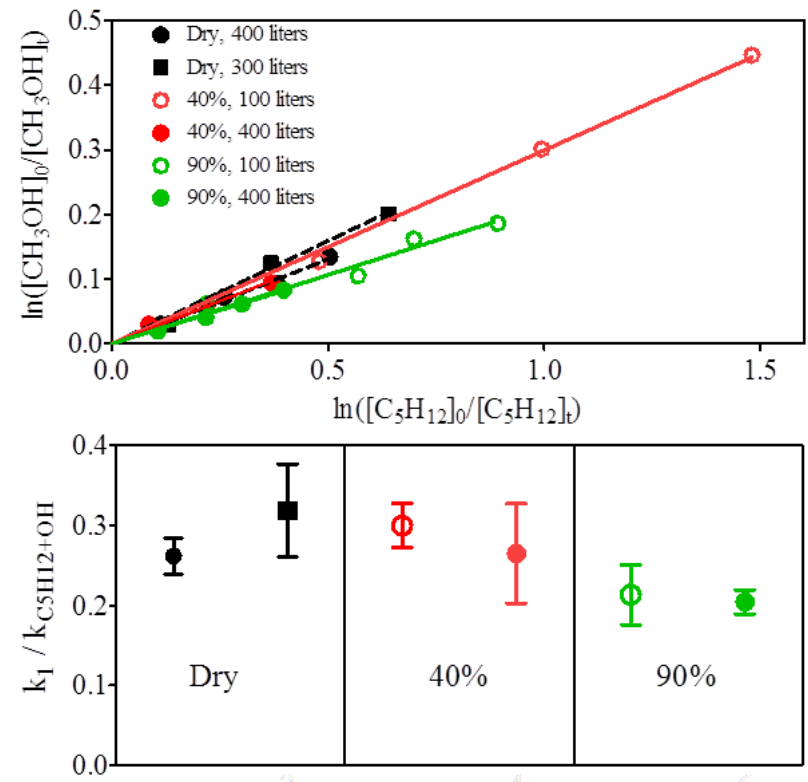

Figure 6. Upper graph: plot of the decay of $\mathrm{CH}_{3} \mathrm{OH}\left(\mathrm{In}\left(\left[\mathrm{CH}_{3} \mathrm{OH}\right]_{0} /\left[\mathrm{CH}_{3} \mathrm{OH}\right]_{\mathrm{t}}\right)\right.$ versus the decay of $\mathrm{C}_{5} \mathrm{H}_{12}\left(\ln \left(\left[\mathrm{C}_{5} \mathrm{H}_{12}\right]_{0} /\left[\mathrm{C}_{5} \mathrm{H}_{12}\right]_{\mathrm{t}}\right)\right.$ for different gas volumes and different $\mathrm{RH}$. Lower graph: slopes of the linear regression of the experiments in the upper graph. Error bars represent 95\% confidence interval. 
Quantum chemistry calculations (CCSD(T)/aug-ccpVTZ//UMP2/aug-cc-pVTZ) and transition state theory (with vibrational perturbation theory including semiclassical tunneling model using the Multiwell program ${ }^{[19]}$ ) were used to simulate the rate coefficients for the $\mathrm{CH}_{3} \mathrm{OH}+\mathrm{OH}+n \mathrm{H}_{2} \mathrm{O}$ reactions. The obtained potential energy surfaces are very similar to those reported by Jara-Toro et al.; both showed lowering of the reaction barriers with increasing $n$ (see $\mathrm{SI}$ for details). We obtained rate coefficients of $2.7 \times 10^{-12} \mathrm{~cm}^{3}$ molecule ${ }^{-1} \mathrm{~s}^{-1}, 1.4 \times 10^{-}$ $32 \mathrm{~cm}^{6}$ molecule ${ }^{-2} \mathrm{~s}^{-1}$, and $4.4 \times 10^{-52} \mathrm{~cm}^{9}$ molecule $\mathrm{e}^{-3} \mathrm{~s}^{-1}$, for the $n$ $=0,1$, and 2 reactions, respectively at $298 \mathrm{~K}$. Even at $\left[\mathrm{H}_{2} \mathrm{O}\right]=$ $6 \times 10^{17} \mathrm{~cm}^{-3}(\mathrm{RH}=92 \%$ at $298 \mathrm{~K})$, the effective bimolecular rate coefficient for $\mathrm{CH}_{3} \mathrm{OH}+\mathrm{OH}$ reaction with $n=1$ will be $8.4 \times 10^{-15}$ $\mathrm{cm}^{3}$ molecule ${ }^{-1} \mathrm{~s}^{-1}$, and that for $n=2$ is $1.6 \times 10^{-15} \mathrm{~cm}^{3}$ molecule ${ }^{-1} \mathrm{~s}$ ${ }^{1}$, which are still orders of magnitude smaller than the $n=0$ rate. That is, even though the reactant complexes are stabilized with the addition of water molecule(s), the decrease in enthalpy at the transition states is not large enough to overcome the large entropic effect of water complexation (for $n=1,2$ ) at room temperature. Similar reports on negligible water effect has been found for a number of $\mathrm{OH}$ reactions ${ }^{[20,[21]}$, it would require either

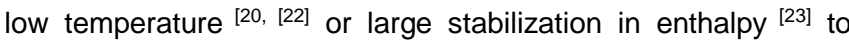
observe significant water enhancement. For theoretical predictions and interpretations, it is important to calculate the reaction rates; only showing the electronic energy on the reaction path could often be misleading if one does not consider the associated entropy change.

It is interesting to mention that the reaction between $\mathrm{CH}_{3} \mathrm{OH}$ and $\mathrm{OH}$ in liquid water has been well studied and is evaluated to be $9.7 \times 10^{8} \mathrm{M}^{-1} \mathrm{~s}^{-1}\left(1.6 \times 10^{-12} \mathrm{~cm}^{3} \mathrm{~s}^{-1}\right)$ at $298 \mathrm{~K}$ and $1 \mathrm{~atm}^{[24]}$, which is close to the gas phase value, suggesting the water solvation does not enhance the rate dramatically.

In summary, our direct kinetic experiments, our relative rate measurements as well as the theoretical rate calculations all find that water catalysis in the $\mathrm{OH}+\mathrm{CH}_{3} \mathrm{OH}$ gas-phase reaction is insignificant at room temperature. No explanation can be given about the origin of the contradictory observations made by JaraToro et al., but it can be speculated that unidentified heterogeneous reactions biased their results. This highlights the need of different approaches for getting reliable results.

\section{Acknowledgements}

The authors thank the French Ministry of Europe and Foreign Affaires and the Taiwan Ministry of Science and Technology for funding through the PHC Orchid program (project no. $40930 \mathrm{YC}$, MOST106-2113-M-001-026-MY3, 107-2911-I-001-507). CF, CS, SB and AT thank the French ANR agency under contract No. ANR-11-LabX-0005-01 CaPPA (Chemical and Physical Properties of the Atmosphere), the Région Hauts-de-France, the Ministère de l'Enseignement Supérieur et de la Recherche (CPER Climibio) and the European Fund for Regional Economic Development for continuous funding. WC thanks Academia Sinica for travel support. KT thanks the Ministry of Science and Technology of Taiwan (107-2113-M-001 -002 -) and Academia Sinica (CDA-106-M05). The authors thank G. Vanhove for calibrating the $\mathrm{CH}_{3} \mathrm{OH}$ concentration.

\section{Conflict of interest}

The authors declare no conflict of interest

Keywords: Alcohols • Atmospheric chemistry • Radical reactions $\cdot$ Reaction mechanism $\bullet \mathrm{OH}$ radicals

\section{References}

[1] B. G. Heikes, W. N. Chang, M. E. Q. Pilson, E. Swift, H. B. Singh, A. Guenther, D. J. Jacob, B. D. Field, R. Fall, D. Riemer, L. Brand Global Biogeochem. Cycles 2002, 16, 13.

[2] A. Mellouki, T. J. Wallington, J. Chen, Chem. Rev. 2015, 115, 3984-4014.

[3] J. J. Orlando, G. S. Tyndall, Chem. Soc. Rev. 2012, 41, 6294-6317.

[4] J.-F. Müller, Z. Liu, V. S. Nguyen, T. Stavrakou, J. N. Harvey, J. Peeters, Nat. Commun. 2016, 7, 13213.

[5] R. L. Caravan, M. A. H. Khan, J. Zádor, L. Sheps, I. O. Antonov, B. Rotavera, K. Ramasesha, K. Au, M.-W. Chen, D. Rösch, D. L. Osborn, C. Fittschen, C. Schoemaecker, M. Duncianu, A. Grira, S. Dusanter, A. Tomas, C. J. Percival, D. E. Shallcross, C. A. Taatjes, Nat. Commun. 2018, 9, 4343.

[6] K. E. Cady-Pereira, M. W. Shephard, D. B. Millet, M. Luo, K. C. Wells, Y. Xiao, V. H. Payne, J. Worden, Atmos. Chem. Phys. 2012 12, 8189-8203.

[7] T. Stavrakou, A. Guenther, A. Razavi, L. Clarisse, C. Clerbaux, P. F. Coheur, D. Hurtmans, F. Karagulian, M. De Maziere, C. Vigouroux, C. Amelynck, N. Schoon, Q. Laffineur, B. Heinesch, M. Aubinet, C. Rinsland, J. F. Muller, Atmos. Chem. Phys. 2011, 11, 4873-4898.

[8] D. B. Millet, D. J. Jacob, T. G. Custer, J. A de Gouw, A. H. Goldstein, T. Karl, H. B. Singh, B. C. Sive, R. W. Talbot, C. Warneke, J. Williams, Atmos. Chem. Phys. 2008, 8, 6887-6905.

[9] D. J. Jacob, B. D. Field, Q. Li, D. R. Blake, J. de Gouw, C. Geophys. Res.-Atmos. 2005, 110, D08303.

[10] D. E. Heard, Acc. Chem. Res. 2018, 51, 2620-2627.

[11] E. Jimenez, M. K. Gilles, A. R. Ravishankara, J. Photochem Photobiol. A 2003, 157, 237-245.

[12] A. Parker, C. Jain, C. Schoemaecker, C. Fittschen, React. Kinet. Catal. Lett. 2009, 96, 291-297.

[13] R. Atkinson, D. L. Baulch, R. A. Cox, J. N. Crowley, R. F. Hampson, R. G. Hynes, M. E. Jenkin, M. J. Rossi, J. Troe, Atmos. Chem. Phys. 2004, 4, 1461-1738.

[14] R. A. Jara-Toro, F. J. Hernandez, R. A. Taccone, S. I. Lane, G. A. Pino, Angew. Chem. Int. Ed. 2017, 56, 2166-2170. R. A. Jara-Toro, F. J. Hernandez, M. d. I. A. Garavagno, R. A. Taccone, G. A. Pino, Phys. Chem. Chem. Phys. 2018, 20, 2788527896.

[16] R. F. Hansen, M. Blocquet, C. Schoemaecker, T. Léonardis, N. Locoge, C. Fittschen, B. Hanoune, P. S. Stevens, V. Sinha, S. Dusanter, Atmos. Meas. Tech. 2015, 8, 4243-4264.

H. Fuchs, A. Novelli, M. Rolletter, A. Hofzumahaus, E. Y. Pfannerstill, S. Kessel, A. Edtbauer, J. Williams, V. Michoud, S. Dusanter, N. Locoge, N. Zannoni, V. Gros, F. Truong, R. SardaEsteve, D. R. Cryer, C. A. Brumby, L. K. Whalley, D. Stone, P. W. Seakins, D. E. Heard, C. Schoemaecker, M. Blocquet, S. Coudert, S. Batut, C. Fittschen, A. B. Thames, W. H. Brune, C. Ernest, H. Harder, J. B. A. Muller, T. Elste, D. Kubistin, S. Andres, B. Bohn, T. Hohaus, F. Holland, X. Li, F. Rohrer, A. Kiendler-Scharr, R. Tillmann, R. Wegener, Z. Yu, Q. Zou, A. Wahner, Atmos. Meas. Tech. 2017, 10, 4023-4053.

[18] H. Bouzidi, C. Fittschen, P. Coddeville, A. Tomas, Atmos. Environ. 2014, 82, 250-257.

[19] J. R. Barker, T. L. Nguyen, J. F. Stanton, C. Aieta, M. Ceotto, F. Gabas, T. J. D. Kumar, C. G. L. Li, L. L. Lohr, A. Maranzana, N. F. Ortiz, J. M. Preses, P. J. Stimac, Multiwell-2016.

[20] D. L. Thomsen, T. Kurten, S. Jorgensen, T. J. Wallington, S. B. Baggesen, C. Aalling, H. G. Kjaergaard, Phys. Chem. Chem. Phys. 2012, 14, 12992-12999.

[21] R. J. Buszek, J. S. Francisco, J. M. Anglada, Int. Rev. Phys. Chem 2011, 30, 335-369.

[22] E. Voehringer-Martinez, B. Hansmann, H. Hernandez, J. S. Francisco, J. Troe, B. Abel, Science 2007, 315, 497-501.

[23] Y.-H. Lin, C. Yin, W.-H. Lin, Y.-L. Li, K. Takahashi, J. J.-M. Lin, J. Phys. Chem. Lett. 2018, 10.1021/acs.jpclett.1028b03349.

[24] A. Monod, J. F. Doussin, Atmos. Environ. 2008, 42, 7611-7622. 


\section{Entry for the Table of Contents}

\section{COMMUNICATION}

The reaction of $\mathrm{OH}$ radicals with $\mathrm{CH}_{3} \mathrm{OH}$ is the major removal path for $\mathrm{CH}_{3} \mathrm{OH}$ from the atmosphere. In recent works it was found, that this reaction is substantially catalyzed by water. Using direct methods, we reinvestigated the influence of $\mathrm{H}_{2} \mathrm{O}$ on the reaction, and did not find any measurable influence of $\mathrm{H}_{2} \mathrm{O}$ on the rate coefficient.

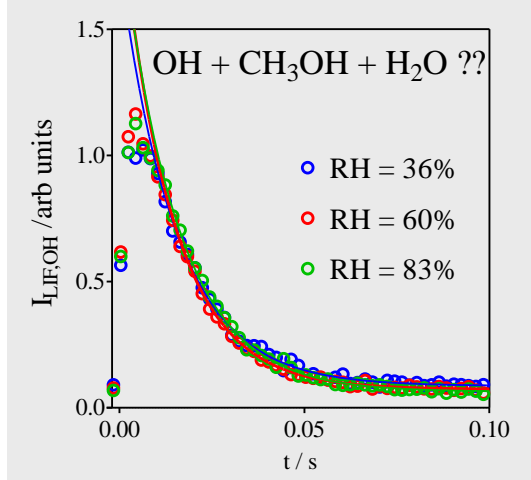

Wen Chao, Dr. Jim Jr-Min Lin, Dr. Kaito Takahashi, Prof. Dr. Alexandre Tomas, Lu Yu, Prof. Dr. Yoshizumi Kajii, Sébastien Batut, Dr. Coralie Schoemaecker, Dr. Christa Fittschen*

Page No. - Page No.

Water Vapor does not Catalyze the Reaction of Methanol and $\mathrm{OH}$ Radicals 